\title{
EARTHQUAKE TRIGGERING EFFECT SCENARIOS DURING THE 2014 SEQUENCE IN CEPHALONIA AND 2015 EARTHQUAKE IN LEFKADA BROADER AREAS, IONIAN SEA, GREECE
}

\author{
Sboras S. ${ }^{1}$, Chatzipetros A. ${ }^{1}$, Pavlides S. ${ }^{1}$, Karastathis V. ${ }^{2}$ and Papadopoulos G. ${ }^{2}$ \\ ${ }^{1}$ Aristotle University of Thessaloniki, Department of Geology, 54124, Thessaloniki, Greece, \\ ssmporas@geo.auth.gr,ac@geo.auth.gr,pavlides@geo.auth.gr \\ ${ }^{2}$ Institute of Geodynamics, Lofos Nymfon,Thisio, Athens, Greece, karastathis@nos.gr
}

\begin{abstract}
In this paper we defined the local complex fault system of the Cephalonia three strongest earthquakes $\left(M_{w} 6.1, M_{w} 5.3\right.$ and $\left.M_{w} 6.0\right)$ of the January-February 2014 sequence and the Lefkada mainshock $\left(M_{w} 6.4\right)$ on November 17, 2015, in order to investigate the fault interaction i) within the 2014 sequence, ii) between the 2014 sequence and the fault that produced the 2015 Lefkada event, and iii) the cumulative effects of all Cephalonia and Lefkada strong events on other neighbouring faults, by calculating the static stress changes. The Coulomb stress change calculations suggest a complex distribution pattern on most of the cases, with only exceptions the F4 fault (Lefkada earthquake), which seems to be barely loaded with stress after the Cephalonia 2014 events, and the "Assos-Skala" fault, which seems to be stress relieved after all Caphalonia 2014 and Lefkada 2015 events.
\end{abstract}

Keywords: fault modelling, stress transfer, Cephalonia, Lefkada; earthquakes.

\section{Пєрі́⿱亠乂 $\psi \eta$}

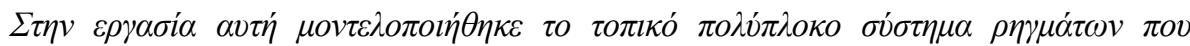

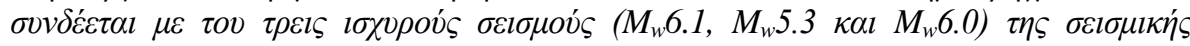

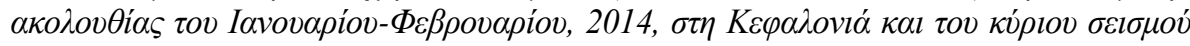

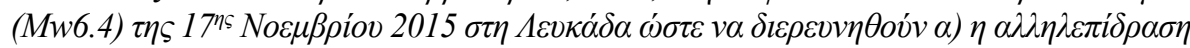

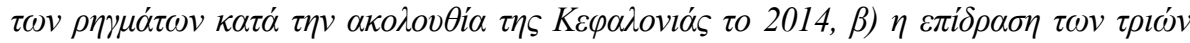

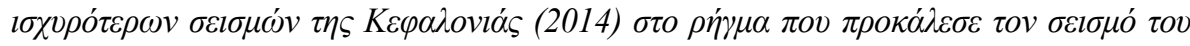

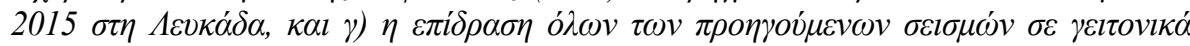

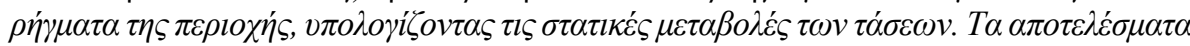

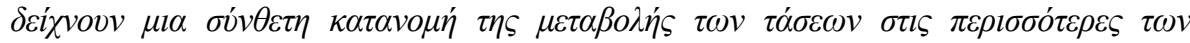

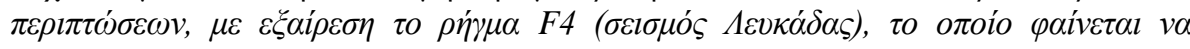

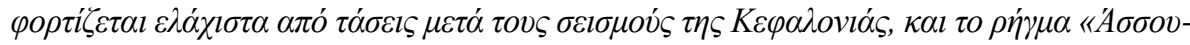

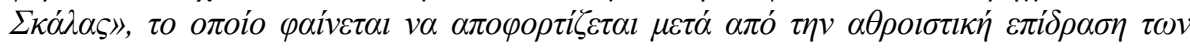

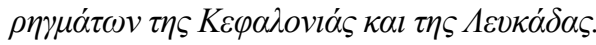

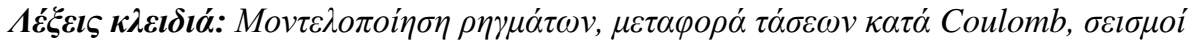

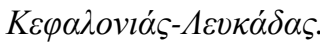




\section{Introduction}

The area of Cephalonia and Lefkada Islands, Ionian Sea, Greece (Figure 1.a), situated in a highly complex tectonic regime, is characterized by very high seismicity. During the last 100 years or so, the area was hit by several large magnitude, lethal earthquakes, the largest one of magnitude 7.2 being recorded on 12 August 1953. On 26 January and 3 February 2014 the western part of Cephalonia Island was heavily affected by three strong, shallow earthquakes measuring momentmagnitude $\left(\mathrm{M}_{\mathrm{w}}\right)$ of 6.1 and 5.2 (January 26) and 6.0 (February 3), respectively (Papadopoulos et al., 2014). Aftershocks were recorded for several months after the first event. In Paliki peninsula, that is the seismic rupture zone (Figure 2), several types of secondary ground failures were also caused by the two strongest shocks, including rockfalls, landslides, soil liquefaction, etc., while extensive local damages were reported (Papadopoulos et al., 2014, Valkaniotis et al., 2014).

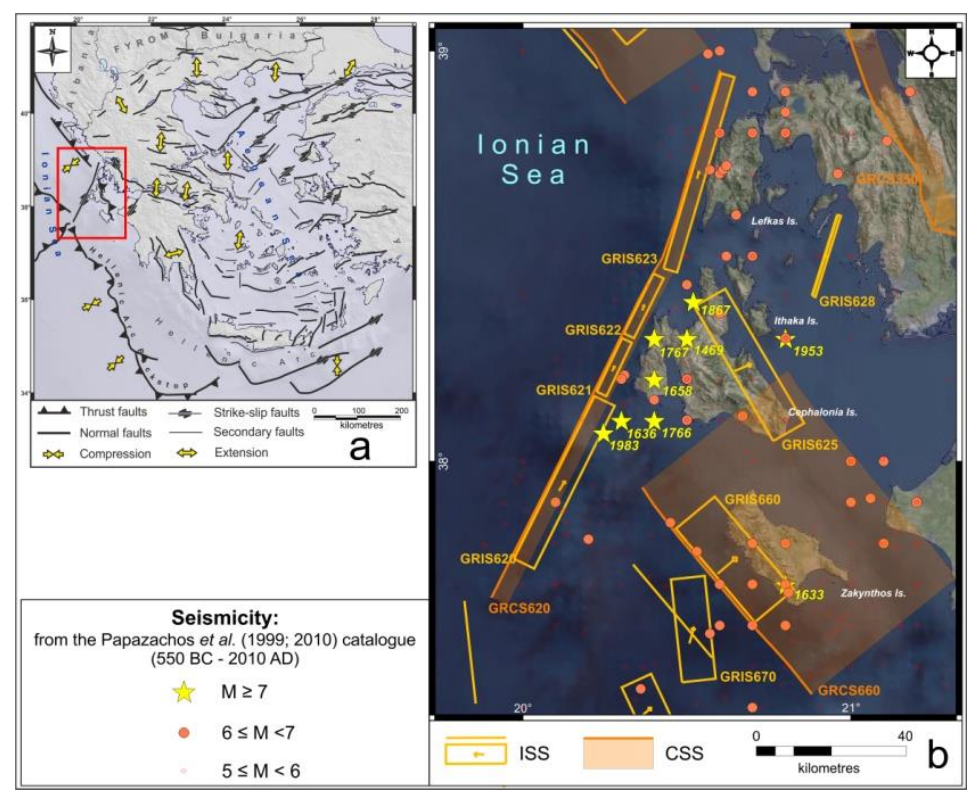

Figure 1 - (a) Geodynamic-neotectonic map of the broader Aegean region (modified after Sboras et al., 2014). Yellow arrows indicate the main stress field axes. The red box represents the borders of map in (b). (b) The seismogenic sources in the surrounding area of Cephalonia and Lefkada islands obtained from GreDaSS (ISSs and CSSs) along with the historical and instrumental seismicity (Seismological Station, AUTh, last visited: September 2014) of the broader study area. The occurrence year is indicated only for earthquakes with $M \geq 7$.

Both 2014 and 2015 seismic crises provide a unique opportunity to better understand such a complex and highly active area. Also the occurrence of the two 2014 Cephalonia strong shocks in close proximity in both time and space is challenging to test models of earthquake triggering effects. This is exactly the aim of this paper by focusing particularly to models of static earthquake triggering due to Coulomb stress changes.

Located in the same geodynamic regime and not far from Cephalonia, Lefkada Island was struck by $\mathrm{a} \mathrm{M}_{\mathrm{w}} 6.2$ earthquake on August 142003 in the same epicentral area with the recent 2015 event (Figure 2), also demonstrating similar aftershock clustering pattern (Benetatos et al., 2005; Papadimitriou et al., 2006) implying rupturing of the same fault zone. The earthquake was followed by extensive secondary ground deformation, such as slope failures, liquefaction phenomena, ground fissures, etc. (Ganas et al., 2015; Papathanassiou et al., 2016), the most intensive of which were observed at the western and southern part of the island. 


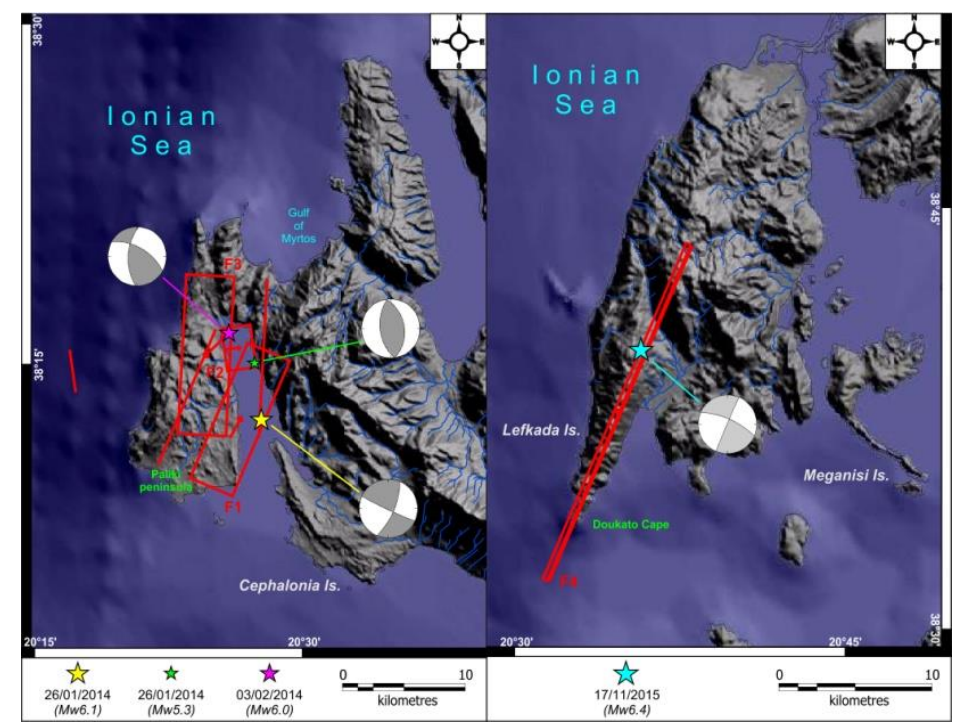

Figure 2 - The fault models of the 2014 Cephalonia (left) and the 2015 Lefkada (right) major earthquakes based on the ISS design philosophy of GreDaSS. The focal mechanisms of the Cephalonia sequence (Papadopoulos et al., 2014) and the Lefkada mainshock (revised moment tensor solution by NOA) were used for the respective fault models.

\section{Seismotectonic Setting}

According to the Greek Database of Seismogenic Sources (GreDaSS; Pavlides et al., 2010; Sboras, 2012; Caputo et al., 2013; http://gredass.unife.it/), the central Ionian Islands are dominated by two faulting modes: a dextral strike-slip (CTFZ) and a reverse dip-slip. The CTFZ is the most representative transcurrent structure in the study area, forming a distinctive scarp right off the western coast of the Cephalonia and Lefkada islands. In GreDaSS, this fault zone has been separated into several fault segments, according to recent seismicity (Table 1; Figure 1b).

The region around the CTFZ is seismically very high with frequent occurrence of large magnitude earthquakes (Papazachos and Papazachou, 1997, 2003; Papadopoulos and Plessa, 2001; Guidoboni et al., 2005; Ambraseys, 2009) (Figure 1b). One of the earliest events reported was a large earthquake ( $\mathrm{M}>7.0,1469 \mathrm{AD}$ ) which caused extensive damage. However, the poor quality of information available for historical earthquakes along with the tectonic complexity of the area does not allow to associate historical earthquakes with their causative faults. Even early instrumental events are hard to be associated with specific faults in the lack of reliable focal mechanisms and/or field observations. The NE-SW-trending crustal shortening along the West Hellenic Arc, the important seismotectonic role of the CTFZ and the negligible motion to the north of CTFZ are evident in geodetic investigations too. According to GPS campaigns (Kahle et al., 1996; Cocard et al., 1999; Hollenstein et al., 2008; Ganas et al., 2013), low velocities are observed to the north of CTFZ, while velocities of approximately $20 \mathrm{~mm} / \mathrm{a}$ and $40 \mathrm{~mm} / \mathrm{a}$ towards $\mathrm{SW}$ are observed around the central Ionian Islands and offshore of the western Peloponnesus, respectively. A dGPS and Permanent Scatterer Interferometric (PSI) analysis conducted by Lagios et al. (2012) on the island of Cephalonia for the time period between 1992 and 2010 shows $i$ ) horizontal clockwise rotation of Cephalonia and velocities ranging from 3 to $8 \mathrm{~mm} / \mathrm{a}$, with the largest values occurring at the western and southern parts of the island, and ii) two distinctive periods of vertical deformation: the first one from 1992 to 2003, when an almost linear slight subsidence (around $1 \mathrm{~mm} / \mathrm{a}$ ) occurred and the second one from 2003 to 2010 , when uplift of $2-4 \mathrm{~mm} / \mathrm{a}$ occurred mainly along the southern and southeastern parts of the island. Larger velocities exceeding $4 \mathrm{~mm} / \mathrm{a}$ took place at the western part of the island. In Paliki Peninsula (western Cephalonia) the total uplift (about $70 \mathrm{~mm}$ ) measured 
during the second time period reached the highest observed amplitudes, but it was of a decreasing rate.

Table 1 - Faults (ISSs) from GreDaSS that have been recognized of producing specific earthquakes in the area of the central Ionian Islands (Fig. 1).

\begin{tabular}{|c|c|c|c|c|}
\hline ISS name & ISS code & $\begin{array}{c}\text { Earthquake } \\
(\text { YYYY/MM/D } \\
\text { D) }\end{array}$ & M $_{w}$ & EQ reference \\
\hline CTFZ segment A & GRIS620 & $1983 / 01 / 17$ & 6.8 & Kiratzi and Louvari, 2003 \\
\hline CTFZ segment B & GRIS621 & $1983 / 03 / 23$ & 6.1 & Kiratzi and Louvari, 2003 \\
\hline CTFZ segment C & GRIS622 & $1972 / 09 / 17$ & 6.2 & Kiratzi and Louvari, 2003 \\
\hline Lefkada Fault & GRIS623 & $2003 / 08 / 14$ & 6.2 & Benetatos et al. 2005 \\
\hline Assos-Skala Fault & GRIS625 & $1953 / 08 / 12$ & 6.9 & EMMA catalogue \\
\hline Kastos Fault & GRIS628 & $1953 / 10 / 21$ & 6.3 & EMMA catalogue \\
\hline Zakynthos SW & GRIS660 & $1959 / 11 / 15$ & 6.8 & Kiratzi and Louvari, 2003 \\
\hline $\begin{array}{c}\text { West-end Hellenic } \\
\text { Arc }\end{array}$ & GRIS670 & $1997 / 11 / 18$ & 6.5 & Kiratzi and Louvari, 2003 \\
\hline
\end{tabular}

\section{Materials and Methods}

\subsection{The 2014 Cephalonia earthquake sequence}

The January-February 2014 seismic sequence ruptured the western Cephalonia between the CTFZ (GRCS620; Table 1) to the west and the "Assos-Skala" fault (GRIS625; Table 1) to the east (Figure 1b). The horizontal distribution of relocated aftershocks (Karastathis et al., 2014; Papadopoulos et al., 2014) covers the entire peninsula of Paliki continuing offshore Myrtos Bay to the north. Three major shocks having magnitudes over 5 occurred in that seismic sequence (Figure 2).

The largest strong mainshock of $\mathrm{M}_{\mathrm{w}} 6.1$, occurred on 26 January 2014. The relocated hypocentral depth is estimated to $16.5 \mathrm{~km}$ (Papadopoulos et al., 2014), while its aftershock distribution occurred above the focal depth having a rather steep, E-dipping trend (Karastathis et al., 2014). The proposed moment tensor by Papadopoulos et al. (2014) shows an almost pure strike-slip, ESE-dipping fault plane (strike/dip/rake $=023^{\circ} / 68^{\circ} / 175^{\circ}$; Figure 2). The second strongest event $\left(\mathrm{M}_{\mathrm{w}} 5.3\right.$, NOA) occurred almost 5 hours after the first one at a relocated depth of $12.5 \mathrm{~km}$. Unfortunately, the aftershock sequence of this event could not be isolated because it overlapped with the mainshock's aftershock sequence. The moment tensor proposed by Papadopoulos et al. (2014) reveals a pure reverse, ENE-dipping fault (strike/dip/rake $=352^{\circ} / 40^{\circ} / 89^{\circ}$; Figure 2).

The third strongest earthquake $\left(\mathrm{M}_{\mathrm{w}} 6.0\right.$, NOA) occurred on 3 February 2014. The relocated hypocentral depth was calculated at $4.6 \mathrm{~km}$ (Papadopoulos et al., 2014). In this case, the finite fault inversion suggests an upward rupture propagation. The moment tensor of Papadopoulos et al. (2014; Figure 2) suggests an oblique-slip, WNW-dipping fault plane with significant reverse component $\left(\right.$ strike $/$ dip/rake $\left.=183^{\circ} / 56^{\circ} / 138^{\circ}\right)$ which is in agreement with $\left.i\right)$ the uplift that was observed in the Paliki Peninsula (e.g. Boncori et al., 2015), and ii) the aftershock spatial distribution which depicts a W-dipping fault plane (Karastathis et al., 2014).

The synthesis of remote sensing and geodetic analysis (Boncori et al., 2015), focused on the February 3 major aftershock of the 2014 earthquake sequence, demonstrated an abrupt change of deformation between the Paliki peninsula and the rest of the island to the east. A roughly N-Strending line north of the Argostoli Gulf, separates the zone of relative uplift (up to $20 \mathrm{~cm}$ ) and of northward motion (up to $35 \mathrm{~cm}$ ) of the Paliki peninsula to the west from the eastern part of the island. 
Similar results based on SAR interferometry were found by Benekos et al. (2014) and Briole et al. (2015). They proposed a maximum uplift of at least $12 \mathrm{~cm}$ at the central part of the Paliki peninsula, spanning the time period over the three major events of the 2014 sequence.

Fieldwork performed in the epicentral area after the mainshock of January 26, 2014, and the aftershock of February 3, 2014, revealed the absence of any primary ground ruptures, but the existence of several types of secondary effects, e.g. ground fissures, liquefaction, rock falls and landslides (Papadopoulos et al., 2014, Valkaniotis et al., 2014, Chatzipetros et al., 2014).

\subsection{The 2015 Lefkada earthquake}

The November 17, 2015 earthquake ruptured the western Lefkada Island (Lat. 38.6662 N, Long. 20.5957 E, NOA; Figure 2), few kilometres east of the CTFZ (GRCS620; Figure 1b), and more particularly the "Lefkada" fault segment (GRIS623). Magnitude and moment were calculated at $\mathrm{M}_{\mathrm{w}} 6.4$ and $\mathrm{M}_{0}=4.402 \mathrm{E}+18 \mathrm{Nm}$ respectively, and focal depth at $10 \mathrm{~km}$. The aftershock spatial distribution (Ganas et al., 2015; Papadimitriou et al., 2015) revealed two clusters in the horizontal pane that occurred due to the accumulated stress at the tips of the strike-slip motion, while the vertical extent is constrained at ca. $12 \mathrm{~km}$ depth. The proposed nodal plane by NOA is: strike $=203^{\circ}$, $\operatorname{dip}=88^{\circ}$, rake $=159^{\circ}$. Preliminary InSAR interferometric images by several researchers show that ground deformation is produced by an onshore fault that is very near and almost parallel to the western coast of Lefkada. Several secondary deformational effects were observed after the earthquake (Ganas et al., 2015; Papathanassiou et al., 2016), such as slope failures, liquefaction phenomena, ground fissures, etc., especially near the western and southern coast of the island.

\section{Fault modelling}

The well relocated epicentral locations and seismic sequence of Karastathis et al. (2014) leave no doubt that the earthquake activity of 2014 was tectonically related neither with the major strike-slip structure of CTFZ (GRCS620) nor with the thrust associated with the 1953 large earthquake (GRIS625; Figure 1b). The mainshock and its aftershocks ruptured the western part of Cephalonia which is situated to the east-southeast of CTFZ, west of the 1953 thrust. Our fault model of the 2014 Cephalonia sequence includes three faults corresponding to the three major events. Henceforth, the January $26^{\text {th }}$ events of $M_{w} 6.1$ and $M_{w} 5.3$ and the February $3^{\text {rd }} M_{w} 6.0$ earthquake were considered to correspond to three distinct faults F1, F2 and F3, respectively (Tab;e 2, Figure 2). Our fault model of the 2015 Lefkada earthquake is represented by F4 fault (Tab;e 2, Figure 2). Several criteria were used to determine the dimensions and the locations of the three faults as explained in the next lines. The average displacement was calculated from seismic moment, applying the relationship $M_{0}=$ $\mu \cdot u \cdot L \cdot W$ (Aki, 1966), where $\mu$ is the shear modulus, $u$ is the average displacement, $L$ is fault length and $W$ is fault width.

\subsection{Fault F1}

The F1 fault is responsible for the $\mathrm{M}_{\mathrm{w}} 6.1$ mainshock (Table 2, Figure 2). To estimate dimensions (length $\times$ width along dip) for this fault several criteria were taken into account. The first is the lateral distribution of the relocated aftershocks occurred during the first week that followed the mainshock (Karastathis et al., 2014): the northern cluster situated around the Bay of Myrtos which separates from the main aftershock cloud, was already active before the mainshock occurrence and, therefore, it was considered that does not belong to the aftershock zone (Papadopoulos et al., 2014). Based on the aforementioned seismological data, the empirical relationships between the earthquake magnitude and the rupture length and area (Wells and Coppersmith, 1994) and the lack of surface coseismic ruptures, we estimated the horizontal and vertical position, the dimensions $(12 \times 10 \mathrm{~km})$ and the direction and dip of the fault plane (Figure 2). Thus, the minimum and maximum fault depth were approximately constrained at 7 and $16 \mathrm{~km}$ respectively. 
Table 2 - Main parameters of the fault models used in the Coulomb stress change calculations. ${ }^{1}$ From GreDaSS. ${ }^{2}$ Values representative for southern CTFZ segments (see Fig. 1b).

\begin{tabular}{|c|c|c|c|c|c|c|}
\hline Fault name (code) & $\begin{array}{c}\text { Strike } \\
\left({ }^{\circ}\right)\end{array}$ & Dip ( $\left.{ }^{\circ}\right)$ & Rake $\left(^{\circ}\right)$ & $\begin{array}{c}\text { Length } \\
(\mathbf{k m})\end{array}$ & $\begin{array}{c}\text { Width } \\
(\mathbf{k m})\end{array}$ & $\begin{array}{c}\text { Min. depth } \\
(\mathbf{k m})\end{array}$ \\
\hline F1 & 23 & 68 & 175 & 12 & 10 & 7 \\
\hline F2 & 352 & 40 & 89 & 3.5 & 3.1 & 10.5 \\
\hline F3 & 183 & 56 & 138 & 13 & 7 & 4 \\
\hline F4 & 203 & 88 & 159 & 24 & 9 & 3.5 \\
\hline $\begin{array}{c}\text { Assos-Skala } \\
(\text { GRIS625) }\end{array}$ & 330 & 56 & 83 & 42 & 17 & 0 \\
\hline Lefkada (GRIS623) $^{1}$ & 16 & 72 & 178 & 55 & 12 & 0 \\
\hline CTFZ southern system $^{2}$ & 25 & 65 & 180 & $16-49$ & $8-12$ & 0 \\
\hline Kastos (GRIS628) & 17 & 85 & -160 & 23 & 9 & 3 \\
\hline
\end{tabular}

\subsection{Fault F2}

The F2 fault corresponds to the second major shock $\left(\mathrm{M}_{\mathrm{w}} 5.3\right)$ of the Cephalonia sequence (Table 2, Figure 2). Its dimensions were estimated only from empirical relationships (Wells and Coppersmith, 1994), since no other relevant information was available. Thus, a small fault plane of $3.5 \mathrm{~km}$ in length and $3.1 \mathrm{~km}$ in width was used for such a moderate magnitude. The relocated hypocenter was the only evidence available about the approximate location of the fault plane. All of the rest parameters (strike, dip and rake) were obtained from the focal mechanism of Papadopoulos et al. (2014).

\subsection{Fault F3}

The F3 fault corresponds to the $\mathrm{M}_{\mathrm{w}} 6.0$ second largest shock of the Cephalonia sequence (Table 2, Figure 2). The vertical aftershock distribution (Karastathis et al., 2014), the uplift of the Paliki peninsula shown in remote sensing imagery (Benekos et al., 2014; Boncori et al., 2015; Briole et al., 2015), the lack of primary coseismic ground ruptures, the relocated hypocentre at about $5 \mathrm{~km}$ and the empirical relationships between magnitude and rupture length and area (Wells and Coppersmith, 1994), made a set of criteria to determine both the dimensions (13 km long and $7 \mathrm{~km}$ wide) and the horizontal and vertical fault plane location (min. depth $4 \mathrm{~km}$ ). The uplift of the Paliki peninsula is in agreement with the reverse component of the focal mechanism of Papadopoulos $e t$ al. (2014).

\subsection{Fault F4}

The Fault F4 represents the fault plane that ruptured western Lefkada Island on November 17, 2015 $\left(\mathrm{M}_{\mathrm{w}} 6.4\right.$; Table 2, Figure 2). Based on empirical relationships between magnitude, rupture area and fault length (Wells and Coppersmith, 1994) the fault plane dimensions are estimated $24 \mathrm{~km}$ long and $9 \mathrm{~km}$ wide. Preliminary InSAR results show intensive ground deformation near and along the western coast of the island, matching the horizontal aftershock distribution (Ganas et al., 2015). Taking into account the fault dimensions, the focal depth, the aftershock spatial distribution and the fact that no primary ground ruptures were observed, the minimum depth of the fault plane is set to a depth of $3.5 \mathrm{~km}$.

\subsection{GreDaSS faults}

Our static stress change calculations also involve neighbouring tectonic structures obtained from GreDaSS. These are the E-dipping thrust fault "Assos-Skala" (GRIS625; Table 1, Figure 1), the CTFZ (GRCS620; Figure 1), consisting of four major segments ('segment A': GRIS620 'segment B': GRIS621, 'segment C': GRIS622 and "Lefkada": GRIS623; Table 1; Figure 1) and the "Kastos" fault (GRIS628). The CTFZ was separated into two parts: the CTFZ southern fault system, which includes the three southern segments (GRIS620, GRIS621 and GRIS622), all with almost identical 
geometric and kinematic parameters (strike, dip and rake), and the northern "Lefkada" fault segment (GRIS623), which demonstrates a lightly different orientation from the other three. For this reason, the CTFZ southern fault system is treated as an individual receiver fault in our static stress change calculations (Table 2).

\section{Stress transfer}

\subsection{Methodology}

In the present work, the static fault interaction calculations are based on the Coulomb failure criterion. In order for a fault to slip, Coulomb stress change $\Delta \sigma f$ should exceed a threshold value on its plane: $\Delta \sigma_{f}=\Delta \tau_{s}+\mu^{\prime} \cdot \Delta \sigma_{n}$,

where $\Delta \tau s$ is the shear stress change on the failure plane, $\mu^{\prime}$ is the friction coefficient and $\Delta \sigma n$ is the normal stress change. In order to visualize the areas where stress is increased or decreased for certain type of faulting, we used the Coulomb v3.3 application (Toda et al., 2005) which resolves the shear and normal components of the stress change on a grid or on specified 'receiver' fault planes, in a homogeneous, elastic and isotropic half-space. According to Toda et al., (2011), "source faults" are the faults that have slipped and "receiver faults" are planes with a specified strike, dip and rake, on which the stresses imparted by the source faults.

For the friction coefficient a common value of $\mu^{\prime}=0.4$ was selected (Nalbant et al., 1998; Papadimitriou, 2002) since many authors have supported that the results are not very sensitive to the changes of $\mu^{\prime}$ (e.g. Deng and Sykes, 1997a; 1997b; King et al., 1994; Stein et al., 1997).

\subsection{Stress transfer scenarios and change patterns}

The objective of this paper is to investigate the static stress changes and possible fault interactions i) between the two first earthquakes (F1 and F2 faults) and the third one (F3 fault) of the 2014 Cephalonia seismic sequence, $\mathrm{ii}$ ) between the 2014 Cephalonia sequence (F1, F2 and F3 faults) and the 2015 Lefkada mainshock (F4 fault), and iii) between both the Cephalonia and Lefkada earthquakes (F1, F2, F3 and F4) and adjacent faults in the surrounding area (GreDaSS faults).

\subsubsection{Scenario A: F1, F2 source faults, F3 receiver fault}

Scenario A (Figure 3) involves the calculation of static stress changes produced by the cumulative coseismic displacement of faults F1 and F2 (which are set as source faults) on faults with geometric and kinematic attributes similar to fault F3 (receiver fault). The calculations depth is set to $5 \mathrm{~km}$ based on the hypocentral depth proposed by Papadopoulos et al. (2014). The results show that at the depth of $5 \mathrm{~km}$, near to the nucleation depth of the February 3 event, the southern half of the fault plane is loaded with stresses while the northern half is relieved from them (Figure 3 ). The vertical profiles (Figure $3 \mathrm{~b}$ ) show that stress accumulation mainly derives from the reactivation of the F1 fault. The distribution of static stress change is also analysed on the fault (Figure 3c), after dividing the fault plane in $10 \times 10$ cells. On this figure stress accumulation is concentrated at the upper southern quarter of the fault plane. Slip version analysis suggests rupture initiation at the upper central part of the fault plane (Papadopoulos et al., 2014). The analysis of Sokos et al. (2015) cannot be compared as they used a 2-segment fault model for the February 3 event. 

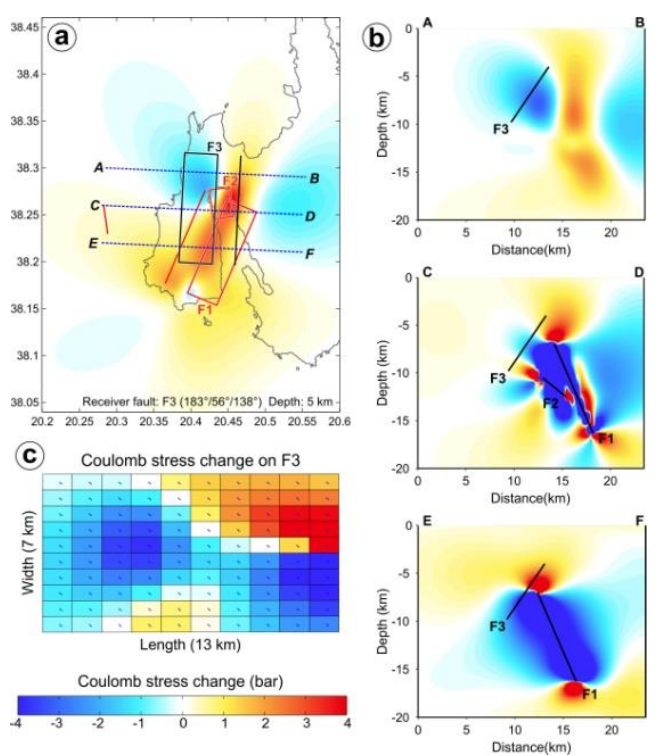

Figure 3 - Coulomb stress change results with F1 and F2 as source faults and F3 as receiver fault. (a) Horizontal distribution at $5 \mathrm{~km}$ depth. (b) Three cross sections perpendicular to F3. (c) On-fault distribution after dividing the fault plane F3 in $10 \times 10$ cells.
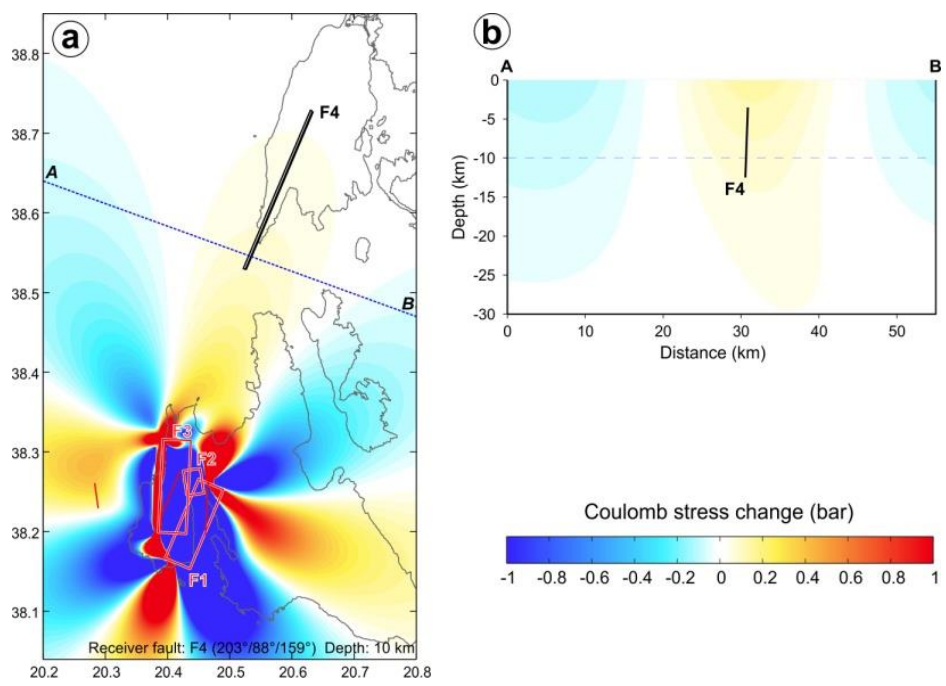

Figure 4 - Coulomb stress change results with F1, F2 and F3 of the Cephalonia 2014 sequence as source faults and F4, the 2015 Lefkada mainshock, as receiver fault. (a) Horizontal distribution at $10 \mathrm{~km}$ depth near to the hypocentral depth of the 2015 Lefkada mainshock. (b) Cross section perpendicular to F4.

\subsubsection{Scenario C: F1, F2, F3 and F4 source faults (2014 Cephalonia and 2015 Lefkada events) and Assos-Skala (GRIS625), CTFZ and Lefkada (GRIS) receiver faults}

Scenario C (Figure 5) involves the calculation of static stress changes produced by the cumulative coseismic displacement of the 2014 Cephalonia and 2015 Lefkada earthquakes (faults F1, F2, F3 and F4, set as source faults) on faults (receiver faults) with geometric and kinematic attributes similar to $i$ ) the three segments of the southern part of the CTFZ system (GRIS620, GRIS621 and GRIS622) represented by common parameters, ii) the "Lefkada" (GRIS623) fault, iii) the "Assos-Skala" 
(GRIS625) fault, and $i v$ ) the "Kastos" (GRIS628) fault. The calculations depth is set to 10 and 15 $\mathrm{km}$ which is a common depth of the hypocentres in the area.

\subsubsection{Scenario B: F1, F2 and F3 source faults (2014 Cephalonia) and F4 receiver fault}

Scenario B (Figure 4) involves the calculation of static stress changes produced by the cumulative coseismic displacement of all three strongest shocks of the 2014 seismic sequence (faults F1, F2 and F3, set as source faults) on faults with geometric and kinematic attributes similar to the fault that produced the 2015 Lefkada mainshock (fault F3, set as receiver fault). The calculations depth is set to $10 \mathrm{~km}$ which is the nucleation depth of the 2015 event (NOA's revised moment tensor solutions). The results show a much lower stress accumulation on F4 fault of the order of 0.2 bar.

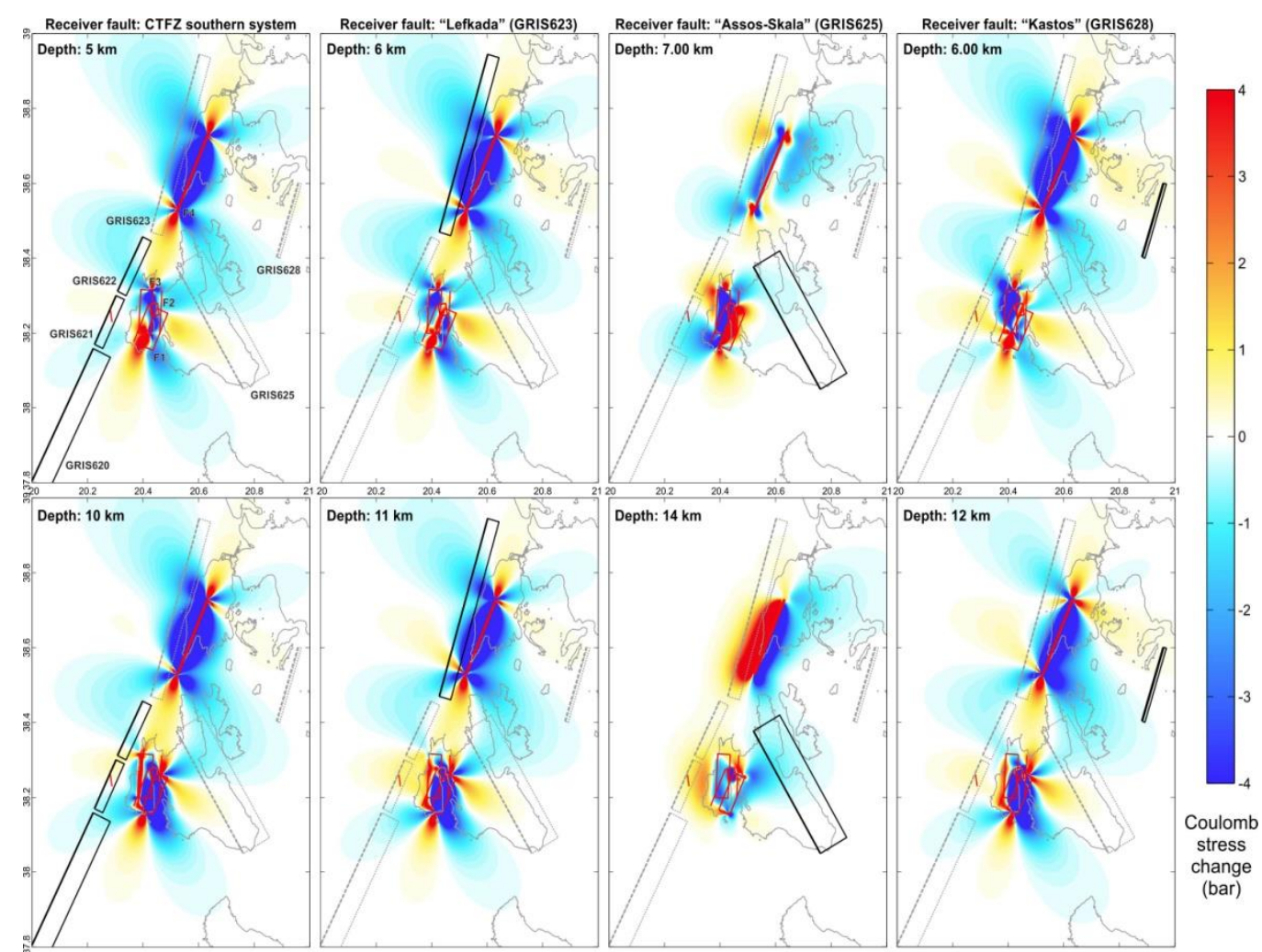

Figure 5 - Horizontal distribution of Coulomb stress changes for two different calculation depths after the 2014 Cephalonia and 2015 Lefkada earthquakes (F1, F2, F3 and F4 faults) on (from left to right) the CTFZ southern fault system, "Lefkada", "Assos-Skala" and

"Kastos" faults, respectively. Source faults are coloured red, receiver faults black and other faults dashed gray.

The CTFZ southern fault system (5 and $10 \mathrm{~km}$ calculation depths) is variously affected, showing the "CTFZ segment A" (GRIS 620) almost unaffected and both "CTFZ segment B" (GRIS621) and "CTFZ segment C" (GRIS622) partially loaded and partially relieved from stresses at both depths. The "Lefkada" (GRIS623) fault is mostly in the stress drop area except two small patches of stress rise near its southern tip for both calculation depths of 6 and $11 \mathrm{~km}$. The only purely reverse "Assos-Skala" (GRIS625) fault demonstrates only stress drop at the biggest part of its fault plane, which becomes even more intensive at its deeper parts $(14 \mathrm{~km})$. The "Kastos" (GRIS628) fault shows only a partial slight stress rise on both calculation depths $(6$ and $12 \mathrm{~km})$ at its northern part. 


\section{Conclusions}

The 2014 Cephalonia seismic sequence consisted of a damaging mainshock on January $26\left(\mathrm{M}_{\mathrm{w}} 6.1\right)$, followed few hours later by a smaller event $\left(\mathrm{M}_{\mathrm{w}} 5.3\right)$. On February 3, the third major and second strongest $\left(\mathrm{M}_{\mathrm{w}} 6.0\right)$ earthquake occurred, rejuvenating the sequence and causing more damage on the island of Cephalonia. From the available seismological and remote sensing data it becomes clear that the 2014 Cephalonia earthquake sequence was produced by faults unknown so far. Located in a geodynamically complex region and spatially constrained between two major tectonic structures (the CTFZ and the "Assos-Skala" fault), the causative fault system demonstrates a complex pattern and behaviour. Based on reassessed seismological data of the 2014 sequence (Papadopoulos et al., 2014; Karastathis et al., 2014) and structural evidence from earlier investigations, we concluded in a 3-fault model that produced the three strongest shocks of the sequence (Table 2; Figure 2). The three faults are more vertically rather than horizontally spaced, showing both reverse and dextral motions. The second one (F2) is the most loosely constrained, while published well-defined data for the first and third earthquake left no room for significant errors as regards the position, geometry and kinematics of the respective F1 and F3 faults.

The 2015 Lefkada sequence was much simpler consisting of the mainshock and its aftershock sequence. The aftershock distribution is concentrated into two main clusters on a NNE-SSW axis. Our fault model (F4) is well enough constrained with minor room for error only on its along-strike position. Preliminary SAR models reveal a ground deformation pattern along the southwestern coast which is in agreement with F4 fault.

Coulomb stress change calculations within the 2015 Cephalonia sequence (Figure 3) show an ambiguous effect of the first two shocks (F1 and F2 faults) on the third strongest shock (F3). Stress change pattern is variably distributed along the fault plane demonstrating high values of both stress drop and rise ( $c a$. -4 to 4 bar, respectively), especially at the upper part where, according to slip inversion model (Papadopoulos et al., 2014), the rupture initiated.

The three strongest shocks of the 2014 Cephalonia sequence seems to have slightly, or practically, hardly affected (stress rise between 0- 0.1 bar) the November 172015 Lefkada earthquake (Figure 4).

The proximity of the Cephalonia and Lefkada strong earthquakes to large tectonic structures, such as the CTFZ and the "Assos-Skala" fault, required to further investigate the stress changes produced by these events on adjacent faults. Using the three fault models of the Cephalonia sequence (F1, F2 and F3) and the fault model of Lefkada's mainshock (F4) as source faults and the faults of GreDaSS as receiver faults, the Coulomb stress change indicated variable patterns on the majority of the neighbouring faults (Figure 5). In fact, the two CTFZ segments "B" and "C" (GRIS621 and GRIS622 respectively) show both stress rise and drop along their strike in both sampling depths of 5 and $10 \mathrm{~km}$. The most distant segment "A" remained practically unaffected, showing a minor stress drop at its northern tip. The "Lefkada" segment (GRIS623) demonstrates a more complex pattern with both stress rise and drop, although stress drop is the dominating state. Stress has moderately decreased ( 1.0 bar) on most of "Assos-Skala" (GRIS625) fault plane, while the rest remained unchanged. Finally, on "Kastos" fault (GRIS628) stress slightly increases along its half northern part, leaving the southern part intact.

\section{References}

Aki, K., 1966. Generation and propagation of G-waves from the Niigata earthquake of June 16, 1964. 2. Estimation of earthquake movement, released energy and stress-strain drop from $\mathrm{G}$ spectrum, Bull. Earthq. Res. Inst., 44, 23-88.

Ambraseys, N., 2009. Earthquakes in the Mediterranean and Middle East: A Multidisciplinary Study of Seismicity up to 1900, Cambridge University Press, New York. 
Benekos, G., Derdelakos, K., Bountzouklis, C. and Kourkouli, P., 2014. Surface displacements of the 2014 Cephalonia (Greece) earthquake using high resolution SAR interferometry, 5th EARSeL Workshop on Remote Sensing and Geology, June 19-20, 2014, Warsaw, Poland, 43-48.

Benetatos, C., Kiratzi, A., Roumelioti, Z., Stavrakakis, G., Drakatos, G. and Latoussakis, I., 2005. The 14 August 2003 Lefkada Island (Greece) earthquake: focal mechanisms of the mainshock and of the aftershock sequence, J. Seismol., 9(2), 171-190.

Boncori, J.P.M., Papoutsis, I., Pezzo, G., Tolomei, C., Atzori, S., Ganas, A., Karastathis, V., Salvi, S., Kontoes, C. and Antonioli, A., 2015. The February 2014 Cephalonia Earthquake (Greece): 3D Deformation Field and Source Modeling from Multiple SAR Techniques, Seismol. Res. Let., 86(1), early edition.

Briole, P., Elias, P., Parcharidis, I., Bignami, C., Benekos, G., Samsonov, S., Kyriakopoulos, C., Stramondo, S., Chamot-Rooke, N., Drakatou, M.L. and Drakatos, G., 2015. The seismic sequence of January-February 2014 at Cephalonia Island (Greece): constraints from SAR interferometry and GPS, Geophys. J. Int., 203(3), 1528-1540.

Caputo, R., Chatzipetros, A., Pavlides, S. and Sboras, S., 2013. The Greek Database of Seismogenic Sources (GreDaSS): state-of-the-art for northern Greece, Ann. Geophys., 55(5), 859-894.

Chatzipetros, A., Sboras, S. and Pavlides, S., 2014. The Cephalonia (Greece) January 26, 2014 M6.1 earthquake: preliminary interpretation and stress transfer analysis, Geophys. Res. Abstracts, 16, EGU2014-16820.

Cocard, M., Kahle, H.G., Peter, Y., Geiger, A., Veis, G., Felekis, S., Paradissis, D. and Billiris, H., 1999. New constraints on the rapid crustal motion of the Aegean region: recent results inferred from GPS measurements (1993-1998) across the West Hellenic Arc, Greece, Earth Planet. Sci. Lett., 172(1), 39-47.

Deng, J. and Sykes, L.R., 1997a. Evolution of the stress field in southern California and triggering of moderate-size earthquakes: a 200-year perspective, J. Geophys. Res., 102, 9859-9886.

Deng, J. and Sykes, L.R., 1997b. Stress evolution in southern California and triggering of moderate-, small-, and micro-size earthquakes. J. Geophys. Res., 102, 24411-24435.

Ganas, A., Marinou, A., Anastasiou, D., Paradissis, D., Papazissi, K., Tzavaras, P. and Drakatos, G., 2013. GPS-derived estimates of crustal deformation in the central and north Ionian Sea, Greece: 3-yr results from NOANET continuous network data, J. Geodyn., 67, 62-71.

Ganas, A., Briole, P., Papathanassiou, G., Bozionelos, G., Avallone, A., Melgar, D., Argyrakis, P., Valkaniotis, S., Mendonidis, E., Moshou, A. and Elias, P., 2015. A preliminary report on the Nov 17, $2015 \mathrm{M}=6.4$ South Lefkada earthquake, Ionian Sea, Greece, Report published online on EMSC, 22 pp.

Grandazzi, M., 1954. Le tremblement de terre des îles ioniennes (aout 1953), Annales de Geographie, 340, 431-453.

Hollenstein, C., Müller, M.D., Geiger, A. and Kahle, H.G., 2008. GPS-derived coseismic displacements associated with the 2001 Skyros and 2003 Lefkada earthquakes in Greece, Bull. Seismol. Soc. Am., 98(1), 149-161.

Kahle, H.G., Müller, M.V. and Veis, G., 1996. Trajectories of crustal deformation of western Greece from GPS observations 1989-1994, Geophys. Res. Let., 23(6), 677-680.

Karastathis, V.K., Mouzakiotis, E., Ganas, A. and Papadopoulos, G.A., 2014. High-precision relocation of seismic sequences above a dipping Moho: the case of the January-February 2014 seismic sequence in Cephalonia Isl (Greece), Solid Earth Discuss, 6(2), 2699-2733.

King, G.C.P. and Cocco, M., 2001. Fault interaction by elastic stress changes: New clues from earthquake sequences, Adv. Geophys., 44, 1-38.

King, G., Tselentis, A., Gomberg, J., Molnar, P., Roecker, S., Sinvhal, H., Soufleris, C. and Stock, J., 1983. Microearthquake seismicity and active tectonics of northwestern Greece, Earth Planet. Sci. Lett., 66, 279-288.

King, G.C.P., Stein, R.S. and Lin, J., 1994. Static Stress Changes and the Triggering of Earthquakes, Bull. Seism. Soc. Am., 84(3), 935-953. 
Lagios, E., Papadimitriou, P., Novali, F., Sakkas, V., Fumagalli, A., Vlachou, K. and Del Conte, S., 2012. Combined Seismicity Pattern Analysis, DGPS and PSInSAR studies in the broader area of Cephalonia (Greece), Tectonophysics, 524, 43-58.

Nalbant, S.S., Hubert, A. and King, G.C.P., 1998. Stress coupling between earthquakes in northwestern Turkey and the north Aegean Sea, J. Geophys. Res., 103, 24469-24486.

Papadimitriou, E.E., 2002. Mode of strong earthquake recurrence in the Central Ionian Islands (Greece): possible triggering due to Coulomb Stress Changes generated by the occurrence of previous strong shocks, Bull. Seismol. Soc. Am., 92(8), 3293-3308.

Papadimitriou, P., Kaviris, G. and Makropoulos, K., 2006. The M w= 6.3 2003 Lefkada earthquake (Greece) and induced stress transfer changes, Tectonophysics, 423(1), 73-82.

Papadimitriou, P., Karakonstantis, A., Bozionelos, G., Kapetanidis, V., Kaviris, G., Spingos, I., Millas, C., Kassaras, I. and Voulgaris, N., 2015. Preliminary report on the Lefkada 17 November $2015 \mathrm{Mw}=6.4$ earthquake, Report published online on EMSC, $12 \mathrm{pp}$.

Papadopoulos, G.A. and Plessa, A., 2001. Historical earthquakes and tsunamis of the south Ionian Sea occurring from 1591 to 1837, Bull. Geol. Soc. Greece, 34(4), 1547-1554.

Papadopoulos, G.A., Karastathis, V.K., Koukouvelas, I., Sachpazi, M., Baskoutas, I., Chouliaras, G., Agalos, A., Daskalaki, E., Minadakis, G., Moshou, A., Mouzakiotis, A., Orfanogiannaki, K., Papageorgiou, A., Spanos, D. and Triantafyllou, I., 2014. The Cephalonia, Ionian Sea (Greece), sequence of strong earthquakes of January-February 2014: a first report, Res. Geophys., 4(5441), 19-30.

Papathanassiou, G., Ganas, A., Moshou, A. and Valkaniotis, S., 2016. Geoenviromental effects of the M=6.4 17 November 2015 earthquake on south Lefkada, Ionian Sea, Greece, Bull. Geol. Soc. Greece, 50 , in press.

Papazachos, B. and Papazachou, C., 1997/2003. The earthquakes of Greece. Ed Ziti, Thessaloniki.

Pavlides, S., Caputo, R., Sboras, S., Chatzipetros, A., Papathanasiou, G. and Valkaniotis, S., 2010. The Greek Catalogue of Active Faults and Database of Seismogenic Sources, Bull. Geol. Soc. Greece, 43(1), 486-494.

Sboras, S., 2012. The Greek Database of Seismogenic Sources: seismotectonic implications for North Greece, PhD Thesis, Università degli studi di Ferrara, Italy, 252 pp.

Sboras, S., Pavlides, S., Caputo, R., Chatzipetros, A., Michailidou, A., Valkaniotis, S. and Papathanassiou, G., 2014. The use of geological data to improve SHA estimates in Greece, Boll. Geofis. Teor. Appl., 55(1), 55-67.

Sokos, E., Kiratzi, A., Gallovič, F., Zahradník, J., Serpetsidaki, A., Plicka, V., Janský, J., Kostelecký, J. and Tselentis, G.A., 2015. Rupture process of the 2014 Cephalonia, Greece, earthquake doublet (Mw6) as inferred from regional and local seismic data, Tectonophysics, 656, 131-141.

Stein, R., Barka, A. and Dieterich, J., 1997. Progressive failure on the North Anatolian fault since 1939 by earthquake stress triggering, Geophys. J. Int., 128, 593-604.

Stiros, S.C., Pirazzoli, P.A. and Laborel, J.F., 1994. The 1953 earthquake in Cephallonia (Western Hellenic Arc): costal uplift and halotectonic faulting, Geophys. J. Int., 117(3), 834-849.

Toda, S., Stein, R.S., Richards-Dinger, K. and Bozkurt, S., 2005. Forecasting the evolution of seismicity in southern California: Animations built on earthquake stress transfer, J. Geophys. Res., 110, B05S16.

Toda, S., Stein, R.S., Sevilgen, V. and Lin, J., 2011. Coulomb 33 Graphic-rich deformation and stress-change software for earthquake, tectonic, and volcano research and teaching - user guide, US Geological Survey Open-File Report, 2011-1060, 63 pp.

Valkaniotis, S., Ganas, A., Papathanassiou, G. and Papanikolaou, M., 2014. Field observations of geological effects triggered by the January-February 2014 Cephalonia (Ionian Sea, Greece) earthquakes, Tectonophysics, 630, 150-157.

Vannucci, G. and Gasperini, P., 2004. The new release of the database of Earthquake Mechanisms of the Mediterranean Area (EMMA Ver. 2). Ann. Geofis., supplement to Vol 47, 307-334.

Wells, D.L. and Coppersmith, J.K., 1994. New Empirical Relationships among Magnitude, Rupture Length, Rupture Width, Rupture Area, and Surface Displacement, Bull. Seism. Soc. Am., 84, 974-1002. 